\title{
Texture-Etched $\mathrm{SnO}_{2}$ Glasses Applied to Silicon Thin-Film Solar Cells
}

\author{
Bing-Rui Wu, ${ }^{1}$ Sin-Liang Ou, ${ }^{1}$ Shih-Yung Lo, ${ }^{1}$ Hsin-Yuan Mao, ${ }^{1}$ \\ Jhen-Yu Yang, ${ }^{1}$ and Dong-Sing Wuu ${ }^{1,2}$ \\ ${ }^{1}$ Department of Materials Science and Engineering, National Chung Hsing University, 250 Kuo Kuang Road, Taichung 40227, Taiwan \\ ${ }^{2}$ Department of Materials Science and Engineering, Da-Yeh University, Changhua 51591, Taiwan
}

Correspondence should be addressed to Dong-Sing Wuu; dsw@dragon.nchu.edu.tw

Received 13 December 2013; Revised 8 February 2014; Accepted 9 February 2014; Published 18 March 2014

Academic Editor: Sheng-Po Chang

Copyright (C) 2014 Bing-Rui Wu et al. This is an open access article distributed under the Creative Commons Attribution License, which permits unrestricted use, distribution, and reproduction in any medium, provided the original work is properly cited.

\begin{abstract}
Transparent electrodes of tin dioxide $\left(\mathrm{SnO}_{2}\right)$ on glasses were further wet-etched in the diluted $\mathrm{HCl}$ :Cr solution to obtain larger surface roughness and better light-scattering characteristic for thin-film solar cell applications. The process parameters in terms of $\mathrm{HCl} / \mathrm{Cr}$ mixture ratio, etching temperature, and etching time have been investigated. After etching process, the surface roughness, transmission haze, and sheet resistance of $\mathrm{SnO}_{2}$ glasses were measured. It was found that the etching rate was increased with the additions in etchant concentration of $\mathrm{Cr}$ and etching temperature. The optimum texture-etching parameters were $0.15 \mathrm{wt} . \% \mathrm{Cr}$ in $49 \% \mathrm{HCl}$, temperature of $90^{\circ} \mathrm{C}$, and time of $30 \mathrm{sec}$. Moreover, silicon thin-film solar cells with the p-i-n structure were fabricated on the textured $\mathrm{SnO}_{2}$ glasses using hot-wire chemical vapor deposition. By optimizing the texture-etching process, the cell efficiency was increased from $4.04 \%$ to $4.39 \%$, resulting from the increment of short-circuit current density from 14.14 to $15.58 \mathrm{~mA} / \mathrm{cm}^{2}$. This improvement in cell performances can be ascribed to the light-scattering effect induced by surface texturization of $\mathrm{SnO}_{2}$.
\end{abstract}

\section{Introduction}

Owing to the advantages consisting of low cost, easy fabrication, and environmental friendliness, silicon $(\mathrm{Si})$ is a very promising material for the photovoltaic applications $[1,2]$. Thin-film solar cells based on amorphous silicon (a$\mathrm{Si})$ or microcrystalline silicon $(\mu \mathrm{c}-\mathrm{Si})$ are the most popular products applied to the building-integrated photovoltaics and consumer electronics. Transparent conductive oxide (TCO) films are usually used as the front electrode of thin-film solar cells. For a transparent electrode, the requirements of TCO films are a low sheet resistance $\left(R_{\text {sheet }}\right)$ to minimize the current loss, a low contact resistance to semiconductor layers, and a high transmission of incident light. To completely utilize the incident light, an important technique of the so-called light trapping has been developed using a TCO with suitable surface texture. Schematic diagrams of the light-scattering effects in roughened and smooth TCO glasses are shown in Figure 1. It was indicated that a specific design of TCO films plays an important role in enhancing the performances of thin-film solar cells. A surface-textured TCO can scatter the light greatly and increase the effective optical path length within the active layers [3-6]. A rough TCO film also ensures that the roughness is copied by the film deposited on it, so that the back metal electrode produces an increased scattering of reflected light. Therefore, this would improve both the optical absorption and current density in thin-film solar cells. After that, various randomly textured TCO substrates have been proposed to increase the light scattering. As-deposited and postchemical textured TCOs are both useful to achieve the rough substrates. The common TCO materials applied to thin-film solar cells consist of tin dioxide $\left(\mathrm{SnO}_{2}\right)$ [6] and zinc oxide $(\mathrm{ZnO})[7,8]$. The great majority of glassbased Si thin-film modules are prepared on the fluorinedoped $\mathrm{SnO}_{2}\left(\mathrm{SnO}_{2}: \mathrm{F}\right)$ glasses due to their intrinsic rough surface $[4,5]$. Moreover, the directly deposited or textureetched $\mathrm{ZnO}$ is another attractive method for the fabrication of rough TCO substrate [9-12]. By using the texture-etched $\mathrm{ZnO}$, the quantum efficiency of thin-film solar cells over the whole spectral range can be increased [11, 12]. A further 


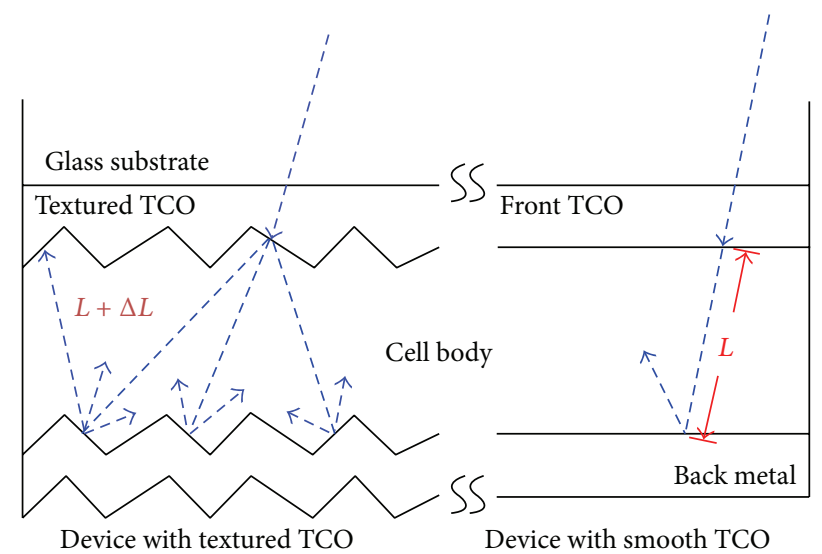

FIGURE 1: Schematic diagrams of the light-scattering effects in roughened and smooth TCO glasses.

improvement in the reduction of free carrier absorption losses in the red/IR and absorption around the optical edge of $\mathrm{ZnO}$ in the blue/UV region can be achieved [13].

$\mathrm{SnO}_{2}$, one of the most common TCO films, is usually prepared by atmospheric pressure chemical vapor deposition (APCVD) with a natively textured surface [14]. Asahi type$\mathrm{U}$ glass is a worldwide TCO substrate for thin-film solar cell industry, which is a natively textured $\mathrm{SnO}_{2}$ glass with the great light scattering of $10 \%$ in transmission haze ratio. A method to create a pattern or to remove the $\mathrm{SnO}_{2}$ layer by wet etching has been reported [15]. The etchant of this method includes 3 liters of $50 \% \mathrm{HCl}$ and $20 \mathrm{~g}$ of chromium metal (Cr). The mixture is heated to $90^{\circ} \mathrm{C}$ with constant stirring to dissolve the $\mathrm{Cr}$. The overall reaction sequence of the etching treatment is given by the following equation:

$$
2 \mathrm{Cr}^{++}+\mathrm{Sn}^{++++} \longrightarrow 2 \mathrm{Cr}^{+++}+\mathrm{Sn}^{++}
$$

where the $\mathrm{SnO}_{2}$ is stannic oxide $\left(\mathrm{Sn}^{++++}\right)$and is transferred to stannous oxide $\left(\mathrm{Sn}^{++}\right)$after the etching reaction. The stannous oxide can be soluble in the acid solution to complete the etching reaction.

In this study, we choose the mass-produced $\mathrm{SnO}_{2}$ soda glasses as substrates which were usually used for the buildingintegrated photovoltaic applications. Then the wet chemical texturization was performed by using the diluted $\mathrm{HCl}: \mathrm{Cr}$ solution to reach larger surface roughness and better lightscattering properties for thin-film solar cell applications. The etching parameters, such as etchant concentration, etching temperature, and etching time $\left(t_{\text {etch }}\right)$, were investigated. Moreover, Si thin-film solar cells with $\mathrm{p}-\mathrm{i}-\mathrm{n}$ structure on various textured $\mathrm{SnO}_{2}$ glasses were fabricated and their characteristics were also studied.

\section{Experimental Procedure}

The 3-mm thick soda glasses with APCVD-deposited $600 \mathrm{~nm}$ thick $\mathrm{SnO}_{2}$ films were chosen as the substrates. These $\mathrm{SnO}_{2}$ glasses showed the high conductivity of 12-14 $\Omega / \square$ and high transparency of $>85 \%$ in the $400-800 \mathrm{~nm}$ wavelength range.
The roughness and transmission haze of $\mathrm{SnO}_{2}$ films were about $260 \mathrm{~nm}$ and $7 \%$, respectively. To obtain the textured surface, the $\mathrm{SnO}_{2}$ glasses were etched in a $\mathrm{SnO}_{2}$ etchant. Various $\mathrm{Cr}$ concentrations from 0.05 to $1 \mathrm{wt} . \%$ were mixed into the diluted $\mathrm{HCl}(49 \%)$ to prepare the $\mathrm{SnO}_{2}$ etchants. The etching temperature was varied from room temperature to $100^{\circ} \mathrm{C}$. Moreover, the $t_{\text {etch }}$ was increased from 1 to $300 \mathrm{sec}$. By changing these parameters, the effects of etching conditions on the optoelectronic performances of $\mathrm{SnO}_{2}$ films were investigated in detail. The ability of the textured $\mathrm{SnO}_{2}$ films to scatter light can be expressed by the transmission haze ratio $\left(H_{t}\right)$ :

$$
\text { Transmission haze }\left(H_{t}\right)=\frac{\text { Diffuse transmittance }}{\text { Total transmittance }},
$$

where the transmission haze is defined as the percentage of transmitted light deviated from the incident beam by more than $2.5^{\circ}$ from the normal incident beam. In this study, the total transmittance was measured by using an integrating sphere. The diffuse transmittance was calculated by the difference between the total and direct transmittance. Considering the rough surface of $\mathrm{SnO}_{2}$, the etching depth was measured repeatedly by an $\alpha$-step surface profiler to determine the average etching rate. Field-emission scanning electron microscope (FE-SEM, JEOL JSM-6700F) was used to observe the $\mathrm{SnO}_{2}$ morphology. An atomic force microscopy (AFM, Agilent 5400) was applied for the measurement of surface roughness. The $R_{\text {sheet }}$ of textured $\mathrm{SnO}_{2}$ film was investigated by using the four-point probe method.

Subsequently, Si thin-film solar cells were fabricated on the textured $\mathrm{SnO}_{2}$ films. The fabrication process can be divided into three main steps: $\mathrm{SnO}_{2}$ texture etching, deposition of the Si p-i-n structure, and formation of the back electrode. The p-type, intrinsic and n-type Si layers in this study were prepared in a single chamber hot-wire chemical vapor deposition (HWCVD) system. The HWCVD technique is widely employed as the fabrication of Si-based thin films consisting of a-Si [16], $\mu \mathrm{c}-\mathrm{Si}$ [17], doped Si [18], and silicon carbide $(\mathrm{SiC})$ [19]. Due to the unique advantages including crystalline film deposition at low substrate temperature, high deposition rate, and high gas utilization in HWCVD [20], it has attracted great attention for its potential applications in thin-film solar cells [21, 22] and transistors [23, 24]. In our previous studies, HWCVD was used to deposit the Sibased films for various purposes, such as aluminum induced crystallization [25], n-type $\mu \mathrm{c}$-Si [26], p-type window layers (nanocrystalline $\mathrm{Si}[27]$ and $\mathrm{SiC}[28]$ ), and heterojunction solar cells [29]. Before loading the $\mathrm{SnO}_{2}$ substrate into HWCVD system, the chamber was firstly treated using the atomic $\mathrm{H}$ generated from $\mathrm{H}_{2}$ gas [30]. Table 1 summarizes the process parameters of HWCVD-deposited p-, i-, and n-type $\mathrm{Si}$ and buffer layers. The key parameters of Si film deposition include a wire temperature of $1700^{\circ} \mathrm{C}$, a substrate temperature of $300^{\circ} \mathrm{C}$, and the working pressure of $100 \mathrm{mTorr}$. Silane $\left(\mathrm{SiH}_{4}\right)$ was applied to the source gas with flow rate $\left(\Phi_{\mathrm{SiH}_{4}}\right)$ of $2 \mathrm{sccm}$. Phosphine $\left(\mathrm{PH}_{3}, 1 \%\right.$ in $\left.\mathrm{H}_{2}\right)$ and diborane $\left(\mathrm{B}_{2} \mathrm{H}_{6}, 1 \%\right.$ in $\left.\mathrm{H}_{2}\right)$ were used as the dopant gases with flow rates $\left(\Phi_{\text {dopant }}\right)$ of 18 and $20 \mathrm{sccm}$, respectively, to prepare n-type and p-type microcrystalline Si layers, which were reported 
TABLE 1: Deposition parameters and properties of p-, i-, n-type Si and buffer layers by HWCVD.

\begin{tabular}{|c|c|c|c|c|c|}
\hline Film & Unit & p-layer & Buffer & i-layer & n-layer \\
\hline Filament temperature & ${ }^{\circ} \mathrm{C}$ & 1700 & 1700 & 1700 & 1700 \\
\hline Substrate temperature & ${ }^{\circ} \mathrm{C}$ & 300 & 300 & 300 & 300 \\
\hline Pressure & mTorr & 100 & 100 & 100 & 100 \\
\hline Gas flow rate $(\Phi)$ & $\mathrm{sccm}$ & $\begin{aligned} \Phi_{\mathrm{SiH}_{4}} & =2 \\
\Phi_{\mathrm{B}_{2} \mathrm{H}_{6}} & =20\end{aligned}$ & $\begin{array}{c}\Phi_{\mathrm{SiH}_{4}}=1 \\
\Phi_{\mathrm{CH}_{4}}=1 \\
\Phi_{\mathrm{B}_{2} \mathrm{H}_{6}}=3 \\
\Phi_{\mathrm{H}_{2}}=20\end{array}$ & $\Phi_{\mathrm{SiH}_{4}}=2$ & $\begin{array}{l}\Phi_{\mathrm{SiH}_{4}}=2 \\
\Phi_{\mathrm{PH}_{3}}=18\end{array}$ \\
\hline Energy gap & $\mathrm{eV}$ & 1.97 & 2.18 & 1.68 & 1.78 \\
\hline Crystalline fraction & $\%$ & 67 & 59 & Amorphous & 57 \\
\hline Deposition rate & $\mathrm{nm} / \mathrm{sec}$ & 0.201 & 0.208 & 0.262 & 0.213 \\
\hline Hall concentration & $\mathrm{cm}^{-3}$ & $1 \times 10^{20}$ & $5 \times 10^{19}$ & - & $4 \times 10^{19}$ \\
\hline
\end{tabular}

elsewhere [25, 27-29]. Some characteristics consisting of energy gap (by Tauc plot), crystalline fraction (by Raman spectroscopy), deposition rate (by profilometer), and Hall concentration (by Hall measurement) of these films were also exhibited in Table 1. The detailed experimental procedures and similar discussions in these films characteristics were presented in our previous works [25, 27-29]. Between the p- and i-layers, a $10 \mathrm{~nm}$ thick p-type microcrystalline $\mathrm{SiC}$ buffer layer with energy gap of $2.18 \mathrm{eV}$ was deposited for better band structure. The main benefit of this buffer layer originated from its effect on the electric field distribution, which minimized the recombination near the $\mathrm{p} / \mathrm{i}$ interface [31]. Compared to the literatures $[32,33]$, the energy gap of our buffer was in good agreement with that of crystalline cubic silicon carbide (3C-SiC). Details of the HWCVDdeposited $\mathrm{SiC}$ were reported in our previous work [28]. The thicknesses of p-, i-, and n-layers were 30,500, and $50 \mathrm{~nm}$, respectively. Such an insufficient i-layer thickness of $500 \mathrm{~nm}$ was used to induce an incomplete absorption. It can provide an investigation of the light-scattering and absorption effects in a limited thickness of absorber layer. After depositing the $\mathrm{p}-\mathrm{i}-\mathrm{n}$ structure, the $500 \mathrm{~nm}$ thick $\mathrm{Ag}$ and $1-\mu \mathrm{m}$ thick $\mathrm{Al}$ layers were grown sequentially as the back electrode by electron-beam evaporation and then annealed at $500^{\circ} \mathrm{C}$ to achieve an ohmic contact. Finally, Si thin-film solar cells were fabricated with the structure of glass/textured $\mathrm{SnO}_{2} / \mathrm{p}$ i-n Si layers/Ag-Al and the cell size was $5 \times 5 \mathrm{~mm}^{2}$. Device performances consisting of current density voltage $(J-V)$ and external quantum efficiency (EQE) of solar cells were measured by Keithley 2400 SourceMeter (Sciencetech, model $\mathrm{SS150W})$ with a one-sun AM1.5G light source $\left(100 \mathrm{~mW} / \mathrm{cm}^{2}\right)$ at room temperature.

\section{Results and Discussion}

This study investigated the improvement in optical characterization of $\mathrm{SnO}_{2}$ films with the optimized textured surface to enhance the spectral response and efficiency of thin-film solar cells. In order to control the etching rate, various $\mathrm{SnO}_{2}$ etchants and etching temperatures were used. As mentioned above, the etchants with various $\mathrm{Cr}$ concentrations from 0.05 to $1 \mathrm{wt}$.\% were employed to etch the $\mathrm{SnO}_{2}$ films. When the
Cr concentration was less than $0.15 \mathrm{wt} . \%$, a poor etching rate approaching to no etching was found on the film surface. On the other hand, the etching reaction was violent for the $\mathrm{Cr}$ concentration more than $0.45 \mathrm{wt} . \%$, leading to a low reproduction in the textured surface. The stable and high reproducible etching reactions have taken place by using the etchants with $\mathrm{Cr}$ concentration of $0.15-0.45 \mathrm{wt} . \%$. Therefore, the etchants with $\mathrm{Cr}$ concentrations of $0.15,0.3$, and $0.45 \mathrm{wt} . \%$ denoted as etchants $\mathrm{A}, \mathrm{B}$, and $\mathrm{C}$, respectively, were chosen to further etch the $\mathrm{SnO}_{2}$ films with various etching conditions (temperature and time). Figure 2 shows the average etching rates of these etchants at various etching temperatures. It was found that the etching reaction appeared when the process temperature was higher than $60^{\circ} \mathrm{C}$. Etching rates of these three etchants were all increased with increasing the temperature. As the temperature was increased from 60 to $100^{\circ} \mathrm{C}$, the etching rates of etchants $\mathrm{A}, \mathrm{B}$, and $\mathrm{C}$ rose from 31.4 , 74.5 , and 89.2 to 121,158 , and $188.6 \mathrm{~nm} / \mathrm{min}$, respectively. The higher $\mathrm{Cr}$ concentration and temperature would result in a higher etching rate.

Various temperatures and $t_{\text {etch }}$ were carried out for etchants $\mathrm{A}, \mathrm{B}$, and $\mathrm{C}$ to optimize the roughness and $H_{t}$ properties of $\mathrm{SnO}_{2}$ films. After comparing all etching results, the higher root-mean-square (RMS) roughnesses and $H_{t}$ values were observed at 90,80 , and $80^{\circ} \mathrm{C}$ for etchants $\mathrm{A}, \mathrm{B}$, and $\mathrm{C}$, respectively. The RMS roughnesses of $\mathrm{SnO}_{2}$ films etched in these three etchants with their optimum temperatures at various $t_{\text {etch }}$ were shown in Figure 3 . Several $t_{\text {etch }}$ of $1,5,15$, $30,60,120$, and $300 \mathrm{sec}$ were used in the etching treatments. From the results, the RMS roughness of $\mathrm{SnO}_{2}$ with these three etchants showed the similar trend to each other. In the range of 1-120 sec, the RMS roughness of $\mathrm{SnO}_{2}$ was firstly increased and then decreased. Because the etching reaction was started at the grain boundaries of film, it induced an increment in RMS in the beginning. The following decrease in RMS with increasing the $t_{\text {etch }}$ to $120 \mathrm{sec}$ was probably ascribed to the isotropic etching in some sharp regions of the grains, causing a smoother surface. After etching for $300 \mathrm{sec}$, we found that the RMS was increased again. It could result from the severe damage on $\mathrm{SnO}_{2}$ surface during long-time etching. For the changes in surface morphology mentioned above, it will be displayed later in SEM images. The highest roughness value 


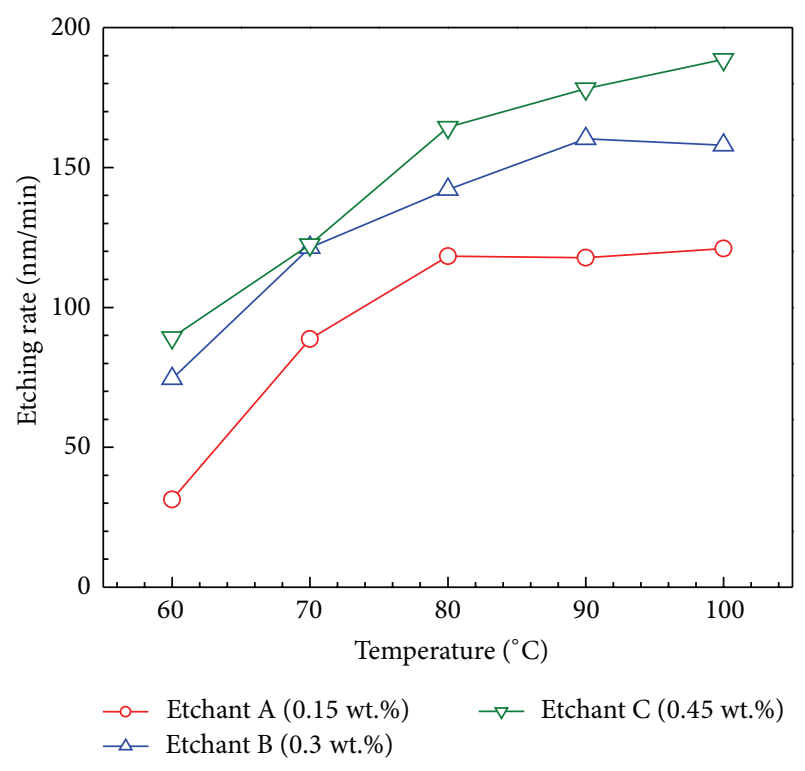

FIGURE 2: Etching rates for $\mathrm{SnO}_{2}$ films in etchants $\mathrm{A}, \mathrm{B}$, and $\mathrm{C}$ as a function of the etching temperature.

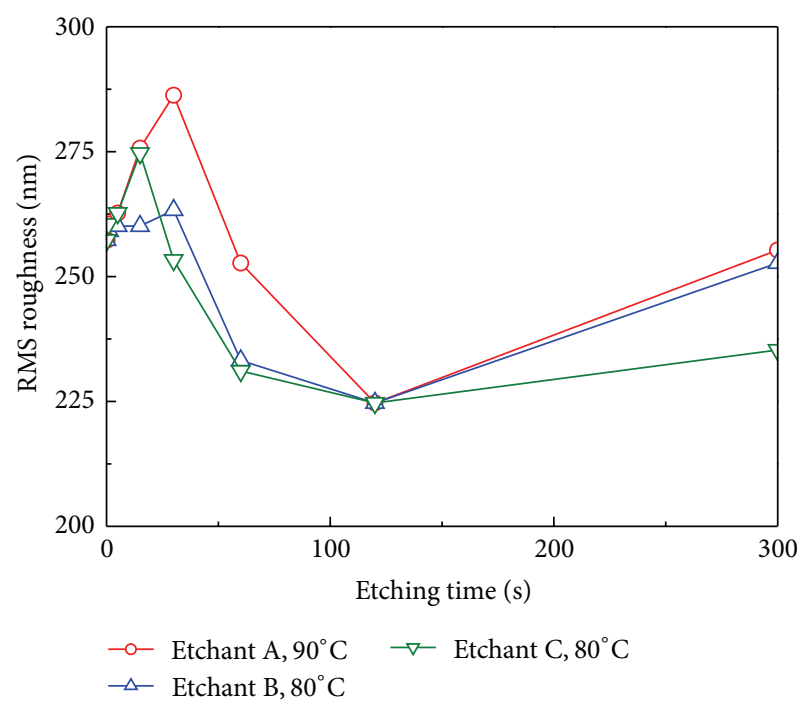

FIgURE 3: Surface RMS roughnesses of etched $\mathrm{SnO}_{2}$ glasses in etchants $\mathrm{A}, \mathrm{B}$, and $\mathrm{C}$ with their optimum temperatures as a function of etching time.

of $286.3 \mathrm{~nm}$ was obtained using the etchant A for $30 \mathrm{sec}$. For etchants B and C, the highest roughness values of 263.3 and $274.7 \mathrm{~nm}$ were found after etching for 30 and $15 \mathrm{sec}$, respectively.

The average $H_{t}$ values (@ $550 \mathrm{~nm}$ ) of $\mathrm{SnO}_{2}$ glasses etched by various etchants as a function of $t_{\text {etch }}$ were shown in Figure 4 . It was found that the $H_{t}$ curves exhibited the similar trends to the results of RMS roughness displayed in Figure 3. In the case of sample treated with etchant $\mathrm{A}$, the $H_{t}$ increased with an increment of $t_{\text {etch }}$ from 1 to $30 \mathrm{sec}$. Further, increasing the $t_{\text {etch }}$ from 30 to $300 \mathrm{sec}$, the $H_{t}$ firstly decreased and then increased. Two relatively high $H_{t}$ values of $8.38 \%$ and $9.13 \%$

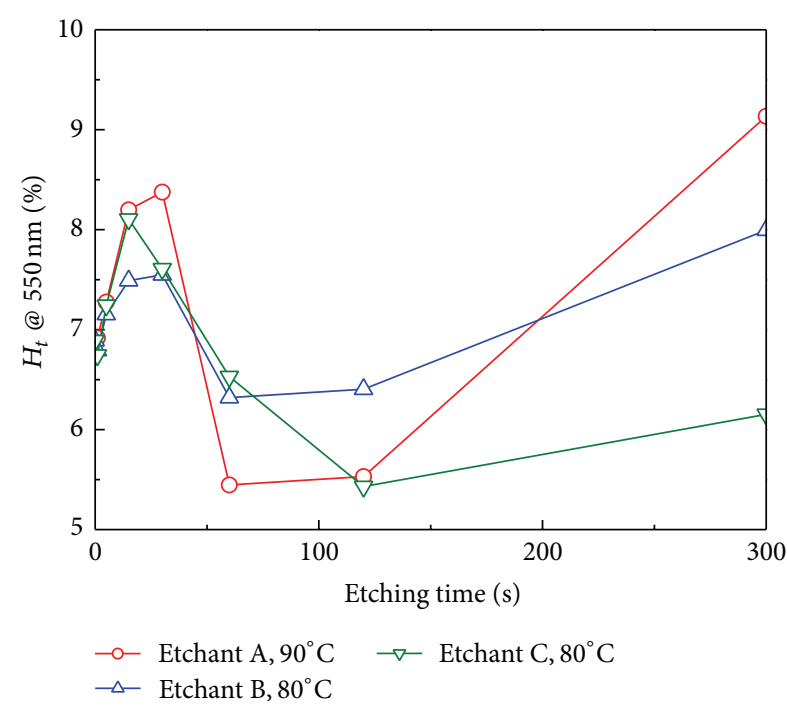

FIGURE 4: Transmission haze (@ $550 \mathrm{~nm}$ ) of etched $\mathrm{SnO}_{2}$ glasses in etchants $\mathrm{A}, \mathrm{B}$, and $\mathrm{C}$ as a function of etching time.

were observed at the $t_{\text {etch }}$ of 30 and $300 \mathrm{sec}$, respectively. Moreover, for the uses of etchants B and $\mathrm{C}$ to our samples, the results demonstrated the similar tendency to each other. The highest $H_{t}$ of samples treated with etchants B and C were 7.55 and $8.1 \%$ after etching for 30 and $15 \mathrm{sec}$, respectively.

The etched $\mathrm{SnO}_{2}$ surface was visualized by the FE-SEM and AFM. Figures 5(a), 5(b), 5(c), and 5(d) showed the SEM images of $\mathrm{SnO}_{2}$ etched in the etchant $\mathrm{A}$ at $90^{\circ} \mathrm{C}$ for $0,30,120$, and $300 \mathrm{sec}$, respectively. The AFM images of same samples were shown in Figures 6(a)-6(d). The RMS and $R_{\text {sheet }}$ of original $\mathrm{SnO}_{2}$ are measured to be $260 \mathrm{~nm}$ and 13.2 $\Omega / \square$, respectively. As displayed in Figures 5(c) and 6(c), some small holes appeared in the $\mathrm{SnO}_{2}$ grains as the $t_{\text {etch }}$ was increased to $120 \mathrm{sec}$. For the $300 \mathrm{sec}$ etching sample, the size of holes was grown up to several hundreds of nanometers as shown in Figures 5(d) and 6(d). In comparison to the nonetching sample, the grain shapes of $\mathrm{SnO}_{2}$ with etching for $30 \mathrm{sec}$ were clearer because the etching usually started at the grain boundaries. After etching for $120 \mathrm{sec}$, the grains became smoother owing to the isotropic nature of wet etching. Nevertheless, with increasing the $t_{\text {etch }}$ to $300 \mathrm{sec}$, the formation of voids can be observed. This indicated that the $\mathrm{SnO}_{2}$ suffered long-time damage by wet chemical etching. These voids may lead to more large-angle scattering light. This could be the reason why these samples with the $t_{\text {etch }}$ of $300 \mathrm{sec}$ exhibited a larger increment in $H_{t}$ than that in RMS roughness. These surface morphologies of $\mathrm{SnO}_{2}$ films with the $t_{\text {etch }}$ from 0 to $300 \mathrm{sec}$ can reflect the various degrees of surface roughness, which is in good agreement with the results shown in Figure 3. The $R_{\text {sheet }}$ values of $\mathrm{SnO}_{2}$ etched for 30,120 , and 300 sec were $13.9,15.1$, and $27.6 \Omega / \square$, respectively. Apparently, the $R_{\text {sheet }}$ increased with increasing the $t_{\text {etch }}$ and hence induced a detrimental effect on the application of thinfilm solar cells. As the etching process was performed for $300 \mathrm{sec}$, there existed a rapid increase in $R_{\text {sheet }}$ due to the chemical damages caused by the long-time etching, as shown 
TABLE 2: Light $J-V$ parameters of silicon p-i-n thin-film solar cells deposited on texture-etched $\mathrm{SnO}_{2}$ with various $t_{\text {etch }}$.

\begin{tabular}{lccccccc}
\hline$t_{\text {etch }}(\mathrm{s})$ & $H_{t 550}(\%)$ & $R_{\text {sheet }}(\Omega / \square)$ & $\eta(\%)$ & $V_{\text {oc }}(\mathrm{V})$ & $J_{\text {sc }}\left(\mathrm{mA} / \mathrm{cm}^{2}\right)$ & $\mathrm{FF}(\%)$ & $R_{s}(\Omega)$ \\
\hline Original & 6.9 & 13.2 & 4.04 & 0.52 & 14.14 & 14.94 & 11.06 \\
30 & 8.38 & 13.9 & 4.39 & 0.52 & 16.58 & 54.24 \\
120 & 5.53 & 15.1 & 4.04 & 0.50 & 14.99 & 49.78 \\
300 & 9.13 & 27.6 & 3.48 & 0.49 & 47.41 & 11.76 \\
\hline
\end{tabular}

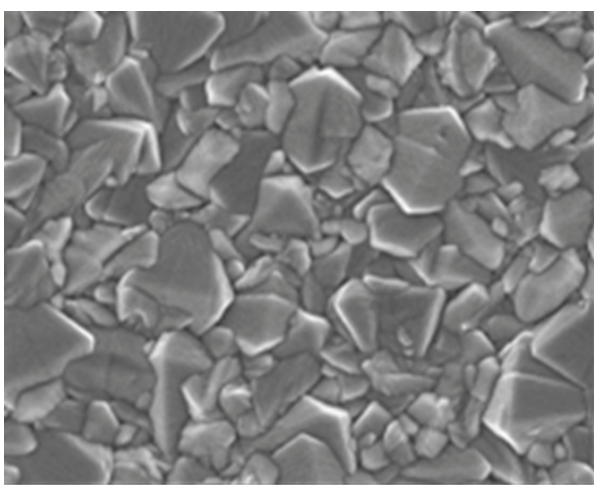

(a)

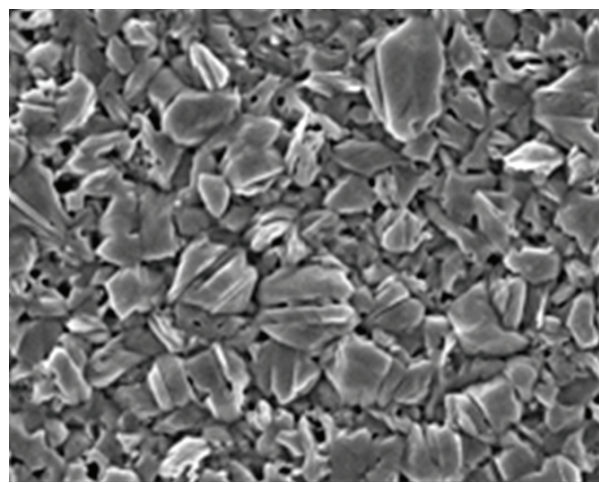

(c)

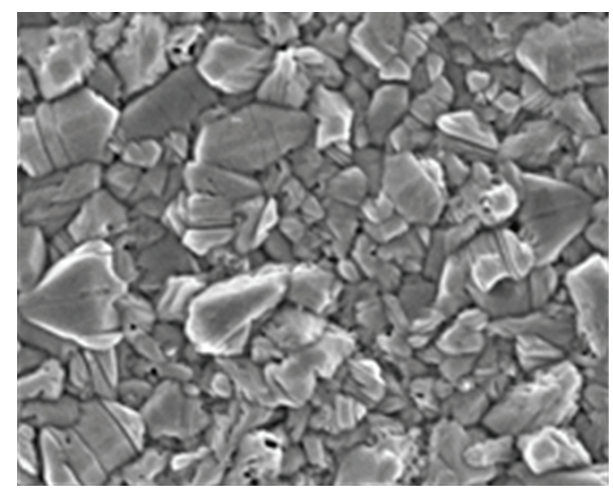

(b)

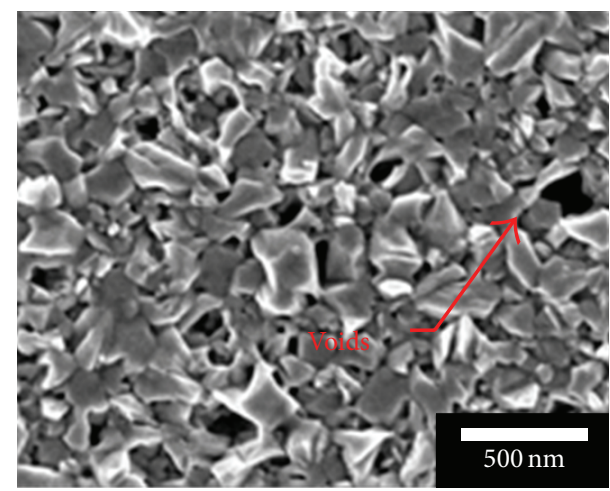

(d)

Figure 5: FE-SEM images of $\mathrm{SnO}_{2}$ etched in the etchant $\mathrm{A}$ at $90^{\circ} \mathrm{C}$ for (a) 0, (b) 30, (c) 120, and (d) $300 \mathrm{sec}$.

in Figures 5(d) and 6(d). Based on the $H_{t}, R_{\text {sheet }}$, and surface roughness of etched $\mathrm{SnO}_{2}$, the $t_{\text {etch }}$ of $30 \mathrm{sec}$ could be an optimum condition in this study.

In order to investigate the improvement in light scattering, the $500 \mathrm{~nm}$ thick a-Si films were deposited upon $\mathrm{SnO}_{2}$ glasses with and without texture etching. For the measurements of total transmittance $(T)$ and total reflectance $(R)$ by the integrating sphere, the samples were illuminated from the glass side. A calculated value of $1-R-T$ represented the absorbance of this $\mathrm{SnO}_{2}$ glass with a $500 \mathrm{~nm}$ thick a-Si layer. The value indicated the real quantity of light trapping or light harvesting ability for $500 \mathrm{~nm}$ thick a-Si on a rough $\mathrm{SnO}_{2}$ substrate. It also revealed that the effect of light scattering was modified by wet texturization. The $1-R-T$ and $H_{t}$ values of original and etched $\mathrm{SnO}_{2}$ glasses were shown in Figure 7. We found that both 1-R-T and $H_{t}$ of etched $\mathrm{SnO}_{2}$ for $30 \mathrm{sec}$ were higher than those of the other samples in the visible range of $400-800 \mathrm{~nm}$. It proved that there was an increment in diffuse transmittance for surface-roughened $\mathrm{SnO}_{2}$ glass. In addition, the absorbance of $500 \mathrm{~nm}$ thick a-Si for incident light was improved via the scattering effect. The effects of texturization on optical characteristics were similar to the results of previous research [34]. From our observation, the sample which used etched $\mathrm{SnO}_{2}$ with etchant $\mathrm{A}$ at $90^{\circ} \mathrm{C}$ for $30 \mathrm{sec}$ has higher $1-R-T$ value than that of the others. Thus, we chose the etchant A with the optimum conditions (etching temperature of $90^{\circ} \mathrm{C}$ and $t_{\text {etch }}$ of $30 \mathrm{sec}$ ) as the standard texture-etching process.

To demonstrate the suitability of textured $\mathrm{SnO}_{2}$ glasses for thin-film solar cell applications, $p$-i-n solar cells have been fabricated by HWCVD on original and etched $\mathrm{SnO}_{2}$ glasses with a $500 \mathrm{~nm}$ thick intrinsic absorber layer. Table 2 summarizes the performances of the $p$-i-n solar cells deposited on $\mathrm{SnO}_{2}$ glasses etched with various $t_{\text {etch }}$. From the measurements shown in Table 2, there existed an increment in $R_{\text {sheet }}$ of TCO from 13.2 to $27.6 \Omega / \square$ as the $t_{\text {etch }}$ was increased from 0 to $300 \mathrm{sec}$. It can be expected that the series resistance of cell would increase with increasing the $R_{\text {sheet }}$ of TCO, further 


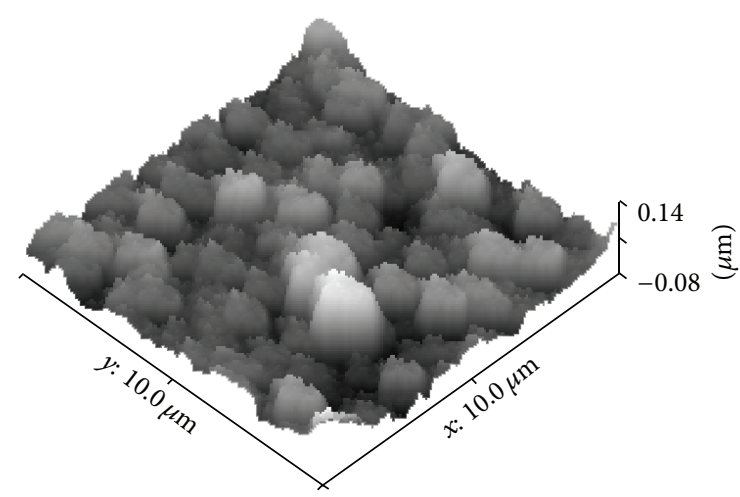

(a)

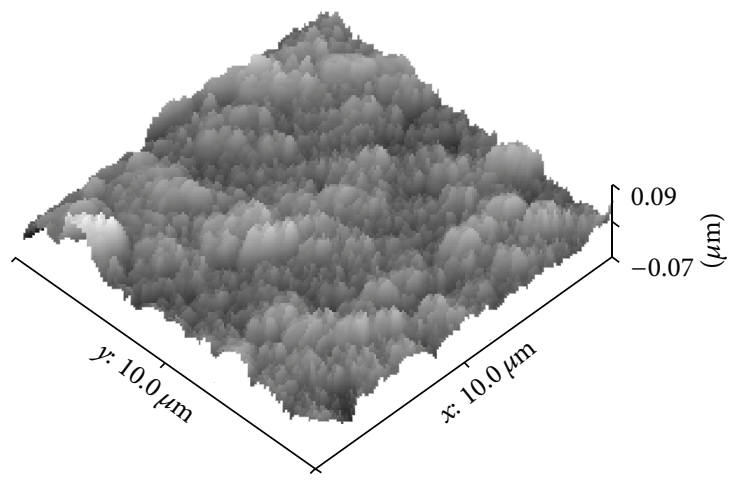

(c)

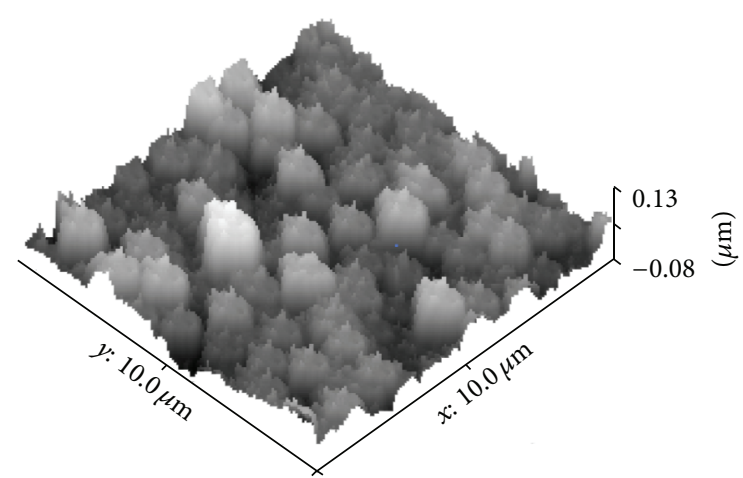

(b)

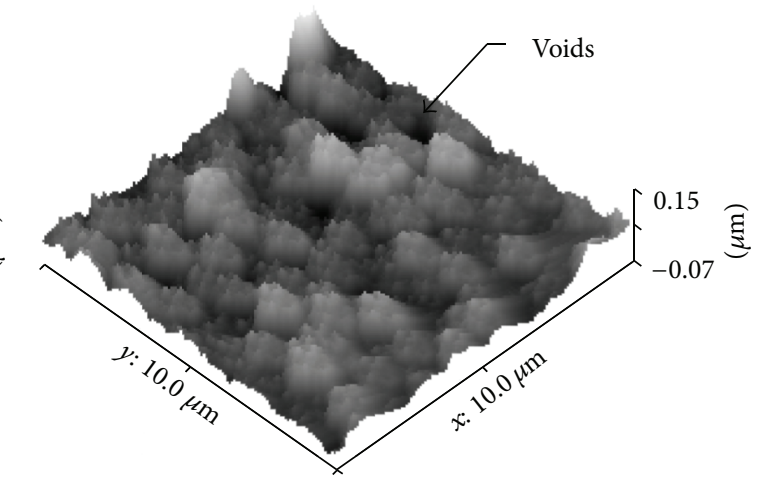

(d)

FIgUre 6: AFM images of $\mathrm{SnO}_{2}$ etched in the etchant $\mathrm{A}$ at $90^{\circ} \mathrm{C}$ for (a) 0, (b) 30, (c) 120, and (d) $300 \mathrm{sec}$.

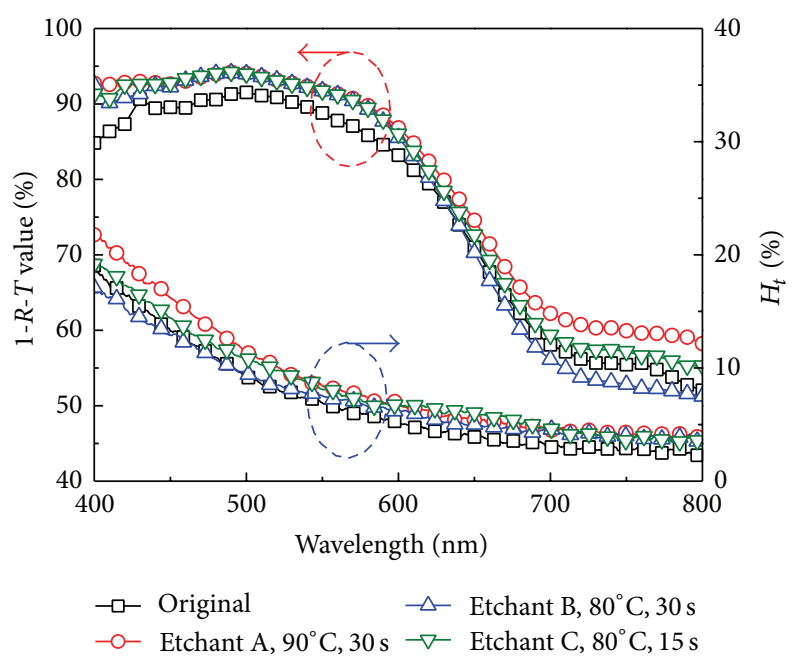

Figure 7: Transmission haze and 1- $R$ - $T$ values of original and etched $\mathrm{SnO}_{2}$ glasses in the visible range of $400-800 \mathrm{~nm}$.

leading to the decreases in fill factor (FF) and conversion efficiency $(\eta)$. In fact, the cell performances in our work are mainly influenced by both $R_{\text {sheet }}$ and roughness of TCO. Generally, the short-circuit current density $\left(J_{\text {sc }}\right)$ of cell can be enhanced by using textured TCO substrate because of the light scattering generated from the rough surface. However, it also results in the deteriorations in open-circuit voltage $\left(V_{\mathrm{oc}}\right)$ and FF of cell [35]. Therefore, it is important to control an acceptable degree of substrate texturization, which can both improve the $J_{\mathrm{sc}}$ and induce the minimum deteriorations in $V_{\mathrm{oc}}$ and FF of cell. As shown in Table 2, the $V_{\mathrm{oc}}$ and FF values of cell with substrate etching for $30 \mathrm{sec}$ were similar to those with nonetched substrate. Nevertheless, with the assistance of etching process for $30 \mathrm{sec}$ to the $\mathrm{SnO}_{2}$ substrate, the $J_{\mathrm{sc}}$ was increased from 14.14 to $15.58 \mathrm{~mA} / \mathrm{cm}^{2}$, while the cell efficiency was increased from $4.04 \%$ to $4.39 \%$. It confirmed that the $t_{\text {etch }}$ of $30 \mathrm{sec}$ was indeed the optimum parameter for substrate texturization in our study. On the other hand, although the $J_{\text {sc }}$ of the samples with substrate etching for 30 and $120 \mathrm{sec}$ were close to each other, there was a considerable difference in their FF values. It can be seen that the cell using longtime $(120 \mathrm{sec})$ etched substrate had the worse FF value of $49.78 \%$ than that with substrate etching for $30 \mathrm{sec}$ (54.24\%). The deteriorated FF value in the sample with substrate etching for $120 \mathrm{sec}$ could be attributed to the higher $R_{\text {sheet }}$ and lower surface roughness of TCO. This revealed that the better light trapping which resulted from the rougher $\mathrm{SnO}_{2}$ surface (wet etching for $30 \mathrm{sec}$ ) can lead to the highest current density of cell device. Moreover, the series resistances $\left(R_{s}\right)$ of 11.06, $10.88,11.76$, and $17.66 \Omega$ were also given in Table 2 for the samples with non-, $30 \mathrm{sec}, 120 \mathrm{sec}$, and $300 \mathrm{sec}$ etched $\mathrm{SnO}_{2}$ substrates, respectively. It was obvious that the much higher 


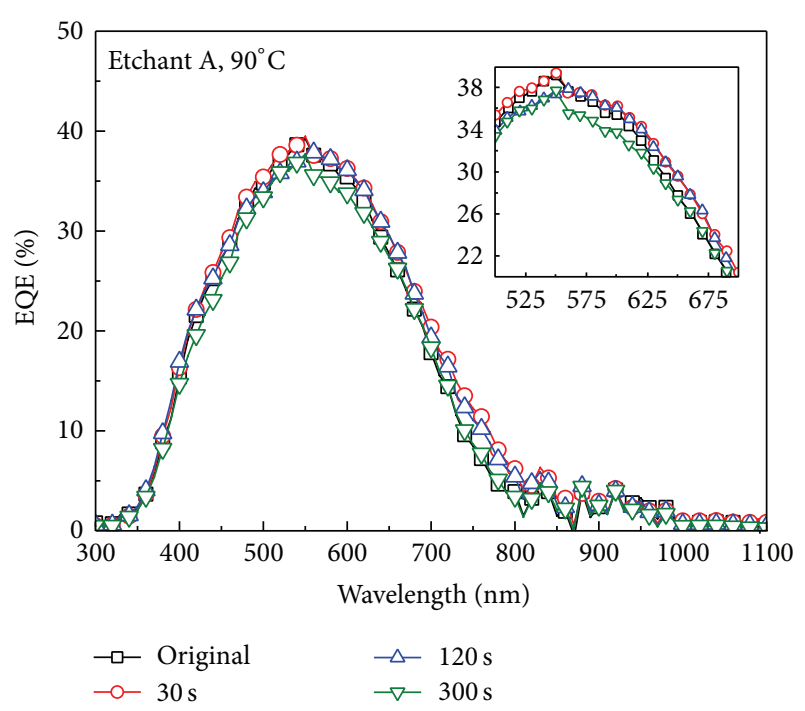

FIGURE 8: EQE characteristics of Si p-i-n solar cells deposited on $\mathrm{SnO}_{2}$ glasses with original and textured (etched in etchant $\mathrm{A}$ at $90^{\circ} \mathrm{C}$ for 30-300 sec) surfaces as a function of measured wavelength. The inset is an enlarged view of Figure 8 focused on the measured wavelength region of 500-700 $\mathrm{nm}$.

$R_{s}$ in the sample with the $t_{\text {etch }}$ of $300 \mathrm{sec}$ was attributed to the long-time etching, resulting in more severe damage on $\mathrm{SnO}_{2}$ surface.

Figure 8 shows the EQE characteristics of solar cells deposited on the original and textured $\mathrm{SnO}_{2}$ glasses. As compared with the solar cell on original $\mathrm{SnO}_{2}$ glass, the device prepared on the $30 \mathrm{sec}$ etched $\mathrm{SnO}_{2}$ exhibited an increase in EQE for almost full range from 300 to $1100 \mathrm{~nm}$. As can be known, the elevation in EQE can enhance the $J_{\mathrm{sc}}$ performance directly. An enlarged view of Figure 8 focused on the measured wavelength region of $500-700 \mathrm{~nm}$ was displayed in the inset. We can find that the cell with $30 \mathrm{sec}$ etched substrate presented a higher EQE value in almost full wavelength ranging from 300 to $900 \mathrm{~nm}$. However, based on the previous study, a-Si solar cell has a low absorption around the wavelength of $800 \mathrm{~nm}$ [36]. Therefore, it can be assumed that the main contribution in EQE for texturized cell happened from near-ultraviolet region to red region $(300-750 \mathrm{~nm})$, which was in good agreement with previous research [37]. This appearance was similar to the $1-R-T$ value shown in Figure 7 . This proved again that the enhancement in $J_{\mathrm{sc}}$ mainly resulted from the light-scattering effect inside of absorber layer by using the textured $\mathrm{SnO}_{2}$ substrate. Furthermore, the $\eta$ of cell devices can be improved from $4.04 \%$ to $4.39 \%$ as the $t_{\text {etch }}$ was increased from 0 to $30 \mathrm{sec}$.

\section{Conclusion}

A wet chemical etching technique using a diluted $\mathrm{HCl}: \mathrm{Cr}$ mixture was applied to the surface texturization of $\mathrm{SnO}_{2}$ glass to enhance the light scattering. It was found that the etchant concentration, etching temperature, and etching time can influence the optoelectronic properties of $\mathrm{SnO}_{2}$ films. From our measurement, the etching rate was increased with increasing the etchant concentration of $\mathrm{Cr}$ and etching temperature. The etchant with appropriate $\mathrm{Cr}$ concentration and etching parameters would lead to the good textured surface and optical characterization. The optimum etching parameters in this work were $0.15 \mathrm{wt} \% \mathrm{Cr}$ in $49 \% \mathrm{HCl}$, temperature of $90^{\circ} \mathrm{C}$, and time of $30 \mathrm{sec}$. With increasing the etching time, the resistance of $\mathrm{SnO}_{2}$ was increased because of the excessive damage to film surface. Moreover, as the optimum etching parameters were used for the surface texturization, the $\mathrm{SnO}_{2}$ glass showed a better transmission haze of $8.38 \%$ as compared to that of original $\mathrm{SnO}_{2}(7 \%)$. Meanwhile, by employing the optimum textured surface, the $J_{\text {sc }}$ of $15.58 \mathrm{~mA} / \mathrm{cm}^{2}$, the $V_{\text {oc }}$ of $0.52 \mathrm{~V}$, the FF of $54.24 \%$, and the $\eta$ of $4.39 \%$ can be obtained in the thin-film solar cell with a $500 \mathrm{~nm}$ thick absorber. It presented about $8.7 \%$ increment in cell efficiency as compared with that using the original $\mathrm{SnO}_{2}$ glass $(\eta=4.04 \%)$. According to the EQE result, this improvement was mainly due to the light absorption in red and infrared regions. It was confirmed that the roughness of APCVD-deposited-SnO $\mathrm{O}_{2}$ surface can be moderately increased using wet chemical etching in a $\mathrm{HCl}$ : $\mathrm{Cr}$ solution. Additionally, with the employment of optimum textured parameters to $\mathrm{SnO}_{2}$ surface, there is a positive influence on the light scattering. This can lead to the enhancements in current density and conversion efficiency of thin-film solar cell.

\section{Conflict of Interests}

The authors declare that there is no conflict of interests regarding the publication of this paper.

\section{Acknowledgment}

This research was supported by the National Science Council of Taiwan, under Contract no. NSC 99-2221-E-005-101-MY3.

\section{References}

[1] C. M. Lee, S. P. Chang, S. J. Chang, and C. I. Wu, "Highefficiency si solar cell fabricated by ion implantation and inline backside rounding process," International Journal of Photoenergy, vol. 2012, Article ID 670981, 7 pages, 2012.

[2] C. M. Lee, S. P. Chang, S. J. Chang, and C. I. Wu, "p-type quasimono silicon solar cell fabricated by ion implantation," International Journal of Photoenergy, vol. 2013, Article ID 171390, 8 pages, 2013.

[3] B. Rech, T. Repmann, M. N. van den Donker et al., "Challenges in microcrystalline silicon based solar cell technology," Thin Solid Films, vol. 511-512, pp. 548-555, 2006.

[4] J. Müller, B. Rech, J. Springer, and M. Vanecek, "TCO and light trapping in silicon thin film solar cells," Solar Energy, vol. 77, no. 6, pp. 917-930, 2004.

[5] K. Yamamoto, A. Nakajima, M. Yoshimi et al., "A high efficiency thin film silicon solar cell and module," Solar Energy, vol. 77, no. 6, pp. 939-949, 2004. 
[6] T. Matsui, M. Tsukiji, H. Saika, T. Toyama, and H. Okamoto, "Influence of substrate texture on microstructure and photovoltaic performances of thin film polycrystalline silicon solar cells," Journal of Non-Crystalline Solids, vol. 299-302, no. 2, pp. 1152-1156, 2002.

[7] T. Söderström, F.-J. Haug, V. Terrazzoni-Daudrix, and C. Ballif, "Optimization of amorphous silicon thin film solar cells for flexible photovoltaics," Journal of Applied Physics, vol. 103, no. 11, Article ID 114509, 2008.

[8] M. Berginski, J. Hüpkes, M. Schulte et al., "The effect of front $\mathrm{ZnO}$ :Al surface texture and optical transparency on efficient light trapping in silicon thin-film solar cells," Journal of Applied Physics, vol. 101, no. 7, Article ID 074903, 2007.

[9] J. Müller, G. Schöpe, O. Kluth et al., "Upscaling of textureetched zinc oxide substrates for silicon thin film solar cells," Thin Solid Films, vol. 392, no. 2, pp. 327-333, 2001.

[10] Y. C. Lin, Y. C. Jian, and J. H. Jiang, "A study on the wet etching behavior of AZO ( $\mathrm{ZnO}: \mathrm{Al})$ transparent conducting film," Applied Surface Science, vol. 254, no. 9, pp. 2671-2677, 2008.

[11] O. Kluth, B. Rech, L. Houben et al., "Texture etched ZnO:Al coated glass substrates for silicon based thin film solar cells," Thin Solid Films, vol. 351, no. 1-2, pp. 247-253, 1999.

[12] Y. Wang, X. Zhang, L. Bai, Q. Huang, C. Wei, and Y. Zhao, "Effective light trapping in thin film silicon solar cells from textured $\mathrm{Al}$ doped $\mathrm{ZnO}$ substrates with broad surface feature distributions," Applied Physics Letters, vol. 100, no. 26, Article ID 263508, 2012.

[13] J. Springer, B. Rech, W. Reetz, J. Müller, and M. Vanecek, "Light trapping and optical losses in microcrystalline silicon pin solar cells deposited on surface-textured glass/ZnO substrates," Solar Energy Materials and Solar Cells, vol. 85, no. 1, pp. 1-11, 2005.

[14] R. G. Gordon, J. Proscia, F. B. Ellis Jr., and A. E. Delahoy, "Textured tin oxide films produced by atmospheric pressure chemical vapor deposition from tetramethyltin and their usefulness in producing light trapping in thin film amorphous silicon solar cells," Solar Energy Materials, vol. 18, no. 5, pp. 263281, 1989.

[15] P. W. Simon, "Etchant and method of etching tin oxide film," Burroughs Corporation, U.S. Patent 4,009,061, 1977.

[16] A. H. Mahan, J. Carapella, B. P. Nelson, R. S. Crandall, and I. Balberg, "Deposition of device quality, low $\mathrm{H}$ content amorphous silicon," Journal of Applied Physics, vol. 69, no. 9, pp. 6728-6730, 1991.

[17] R. O. Dusane, S. R. Dusane, V. G. Bhide, and S. T. Kshirsagar, "Hydrogenated microcrystalline silicon films produced at low temperature by the hot wire deposition method," Applied Physics Letters, vol. 63, no. 16, pp. 2201-2203, 1993.

[18] J. P. Conde, P. Alpuim, M. Boucinha, J. Gaspar, and V. Chu, "Amorphous and microcrystalline silicon deposited by hotwire chemical vapor deposition at low substrate temperatures: application to devices and thin-film microelectromechanical systems," Thin Solid Films, vol. 395, no. 1-2, pp. 105-111, 2001.

[19] T. Wu, H. Shen, B. Cheng, Y. Pan, C. Gao, and J. Shen, "Effect of filament temperature on properties of hot wire CVD deposited nc-3C-SiC films from SiH4-C2H2-H2 mixture," Materials Research Innovations, vol. 16, no. 3, pp. 165-169, 2012.

[20] S. K. Soni, A. Phatak, and R. O. Dusane, "High deposition rate device quality a-Si:H films at low substrate temperature by HWCVD technique," Solar Energy Materials and Solar Cells, vol. 94, no. 9, pp. 1512-1515, 2010.

[21] B. Schroeder, "Status report: solar cell related research and development using amorphous and microcrystalline silicon deposited by HW(Cat)CVD," Thin Solid Films, vol. 430, no. 12, pp. 1-6, 2003.

[22] T. Chen, Y. Huang, D. Yang, R. Carius, and F. Finger, "Microcrystalline silicon thin film solar cells with microcrystalline silicon carbide window layers and silicon absorber layers both prepared by Hot-Wire CVD," Physica Status Solidi: Rapid Research Letters, vol. 4, no. 3-4, pp. 61-63, 2010.

[23] M. Fonrodona, D. Soler, J. Escarré et al., "Low temperature amorphous and nanocrystalline silicon thin film transistors deposited by Hot-Wire CVD on glass substrate," Thin Solid Films, vol. 501, no. 1-2, pp. 303-306, 2006.

[24] B. Stannowski, J. K. Rath, and R. E. I. Schropp, "Thin-film transistors deposited by hot-wire chemical vapor deposition," Thin Solid Films, vol. 430, no. 1-2, pp. 220-225, 2003.

[25] B. R. Wu, S. Y. Lo, D. S. Wuu et al., "Direct growth of large grain polycrystalline silicon films on aluminum-induced crystallization seed layer using hot-wire chemical vapor deposition," Thin Solid Films, vol. 520, no. 18, pp. 5860-5866, 2012.

[26] S.-Y. Lien, D.-S. Wuu, B.-R. Wu, R.-H. Horng, M.-C. Tseng, and H.-H. Yu, "Hot-wire CVD deposited n-type $\mu \mathrm{c}$-Si films for $\mu \mathrm{c}-$ $\mathrm{Si} / \mathrm{c}-\mathrm{Si}$ heterojunction solar cell applications," Thin Solid Films, vol. 516, no. 5, pp. 765-769, 2008.

[27] H.-Y. Mao, S.-Y. Lo, D.-S. Wuu et al., "Hot-wire chemical vapor deposition and characterization of p-type nanocrystalline Si films for thin film photovoltaic applications," Thin Solid Films, vol. 520, no. 16, pp. 5200-5205, 2012.

[28] H.-Y. Mao, D.-S. Wuu, B.-R. Wu, S.-Y. Lo, H.-Y. Hsieh, and R.H. Horng, "Hot-wire chemical vapor deposition and characterization of p-type nanocrystalline $\mathrm{SiC}$ films and their use in $\mathrm{Si}$ heterojunction solar cells," Thin Solid Films, vol. 520, no. 6, pp. 2110-2114, 2012.

[29] S.-Y. Lien, B.-R. Wu, J.-C. Liu, and D.-S. Wuu, "Fabrication and characteristics of $\mathrm{n}-\mathrm{Si} / \mathrm{c}-\mathrm{Si} / \mathrm{p}-\mathrm{Si}$ heterojunction solar cells using hot-wire CVD," Thin Solid Films, vol. 516, no. 5, pp. 747-750, 2008.

[30] A. Masuda and H. Matsumura, "Guiding principles for devicegrade hydrogenated amorphous silicon films and design of catalytic chemical vapor deposition apparatus," Thin Solid Films, vol. 395, no. 1-2, pp. 112-115, 2001.

[31] R. R. Arya, A. Catalano, and R. S. Oswald, "Amorphous silicon p-i-n solar cells with graded interface," Applied Physics Letters, vol. 49, no. 17, pp. 1089-1091, 1986.

[32] A. Tabata, T. Nakajima, T. Mizutani, and Y. Suzuoki, "Preparation of wide-gap hydrogenated amorphous silicon carbide thin films by hot-wire chemical vapor deposition at a low tungsten temperature," Japanese Journal of Applied Physics, Part 2: Letters, vol. 42, no. 1, pp. L10-L12, 2003.

[33] S. Miyajima, A. Yamada, and M. Konagai, "Characterization of undoped, N- and P-type hydrogenated nanocrystalline silicon carbide films deposited by hot-wire chemical vapor deposition at low temperatures," Japanese Journal of Applied Physics, Part 1: Regular Papers and Short Notes and Review Papers, vol. 46, no. 4, pp. 1415-1426, 2007.

[34] J. I. Owen, J. Hüpkes, H. Zhu, E. Bunte, and S. E. Pust, "Novel etch process to tune crater size on magnetron sputtered ZnO:Al," Physica Status Solidi (A) Applications and Materials Science, vol. 208, no. 1, pp. 109-113, 2011.

[35] H. Sai, H. Fujiwara, M. Kondo, and Y. Kanamori, "Enhancement of light trapping in thin-film hydrogenated microcrystalline Si solar cells using back reflectors with self-ordered dimple pattern," Applied Physics Letters, vol. 93, no. 14, Article ID 143501, 2008 . 
[36] A. V. Shah, H. Schade, M. Vanecek et al., "Thin-film silicon solar cell technology," Progress in Photovoltaics: Research and Applications, vol. 12, no. 2-3, pp. 113-142, 2004.

[37] M. L. Addonizio and A. Antonaia, "Surface morphology and light scattering properties of plasma etched $\mathrm{ZnO}$ : $\mathrm{B}$ films grown by LP-MOCVD for silicon thin film solar cells," Thin Solid Films, vol. 518, no. 4, pp. 1026-1031, 2009. 

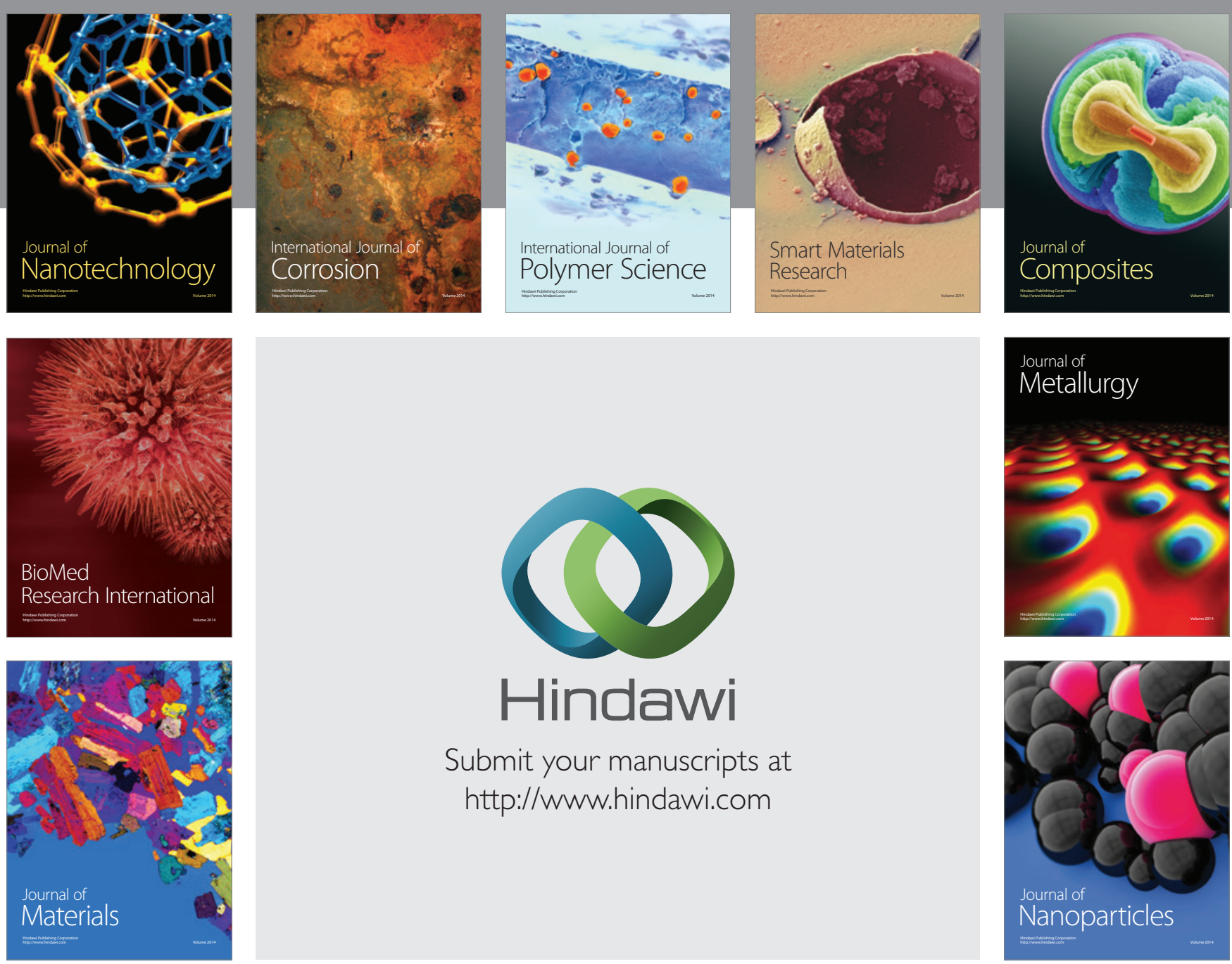

Submit your manuscripts at http://www.hindawi.com
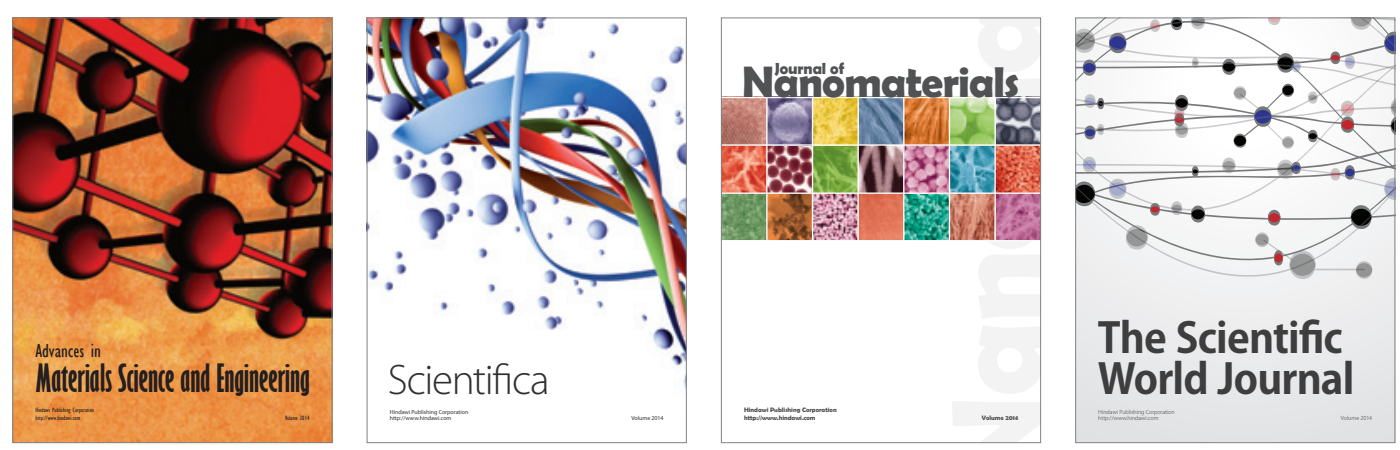

\section{The Scientific World Journal}
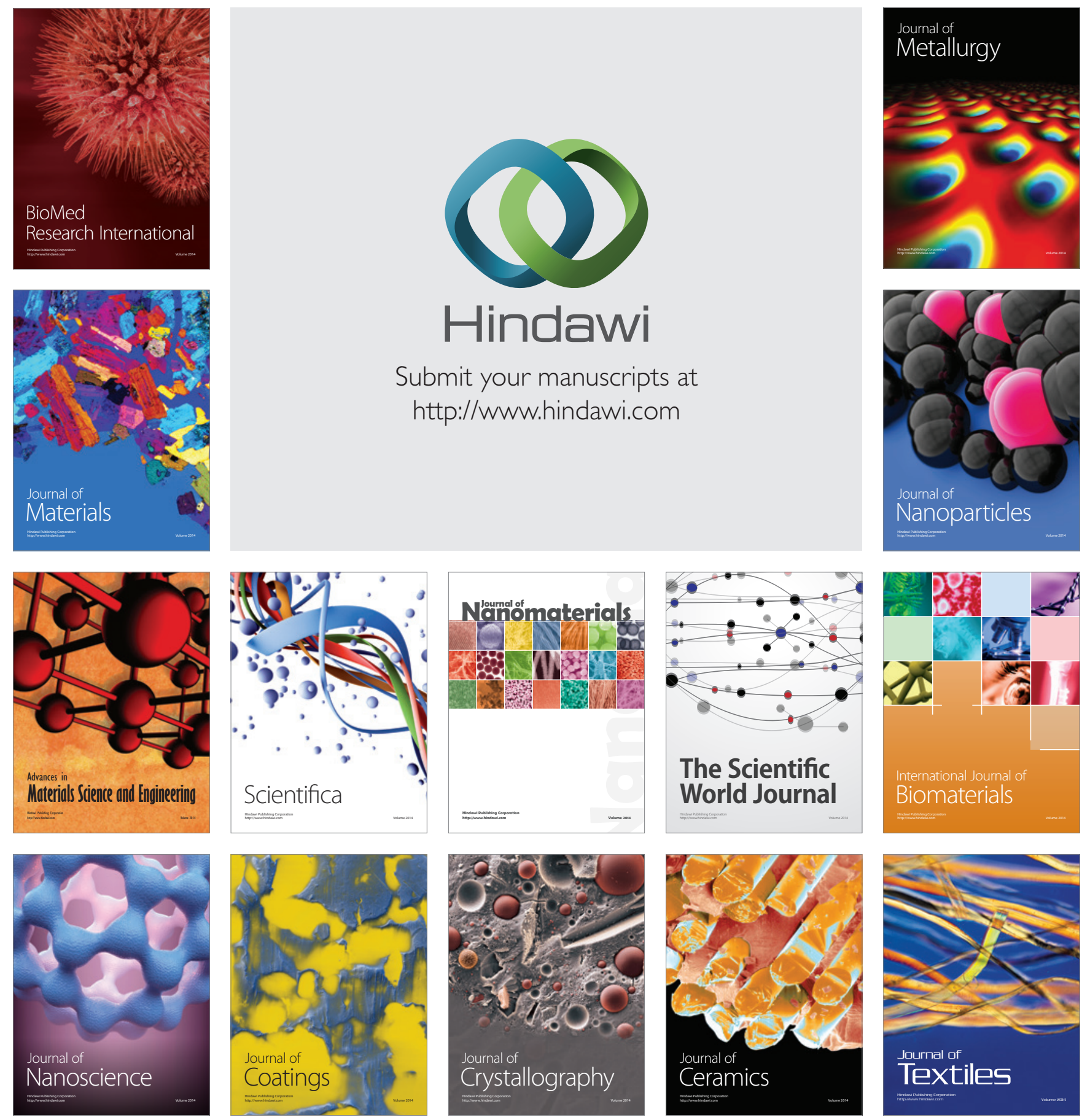